1. Lagleyze.-Archivos de oftalmologia Hispano-Americanos, 1914.

2. van der Hoeve. - Nederl. Tijdschr. v. Geneesk., I9I 5.

3. Arisawa, U.- "Metastatisches Aderhautkarzinom bei latentem Primärtumor." Klin. Monatsbl. f. Augenheilk., Vol. LII, I, p. 695, 1914.

4. Swanzy and Werner.- "Diseases of the lye." Ioth ed., rgr 2.

5. Arisawa. _ "Bericht Ophth. Soc., Heidelberg." Vol. XXXIX, p. 338, I913.

6. Fehr. - "Das Augenspielbild des metastatischen Aderhautcarzinoms." Klin. Monatsbl. f. Augenheilk., Vol. LX, I, p. 74I, I9I8.

7. Oatman, E. L. - "Metastatic carcinoma of the choroid, with report of a case and review of the literature." Amer. Jl. Med. Sciences, Vol. CXXV, p. 375, 1903.

8. Uhthoff, W. - "Zur Lehre vom metastatischen Aderhautcarcinom." Bericht ü 33 oph. Gesellschaft, Heidelberg, I906, p. 193, Wiesbaden, 1907.

o. Gayet.-Arch. d'Ophtal., p. 2 I I, 1889.

10. Kamocki. - Centralbl. f. Augenheilk., p 407, 1884, and Arch. of Ophthal., t. 23, f. I and 2, p. 105, 1894 .

I I. Gelpke, T.-Klin. Monatsbl. f. Augenheilk., Vol. XLIII, I, p. 492, I905.

12. Reis.-Klin. Monatsbl. $f$. Aus enheilk., 4I, Vol. 2, p. 422, IgO3.

13. Paul. - Arch. f. Augenheilk., Vol. LIII, p. I, I905.

14. Oatman. - Loc. cit.

15. Osler and McCrae.-_"Principles and Practice of Medicine." 9th ed., p. 49I, I920.

16. Finlay, D. W. - The Quarterly Journal of viedicine, Vol. V, p. 524, I9I I-I 2.

17. Macmillan.-Arch. of Ophthal., Vol. 1.I, p. 227, 1922.

18. Michel, V.-Zeitschr. f. Aughenheilk., Vol. XIV, p. 42 I, 1905.

19. Parsons.-_" "Pathology of the Eye." Vol. II, p. 54I.

20. Ewing.-Arch.f. Ophthal., Vol. XXXVI, p. $120,1890$.

2I. Lagrange. - "Tumeurs de l'oeil." Vol. I, p. 512, I90I.

22. Briehn. - "Inaugural-Dissertation, Königsberg, I902.

23. Cutler.-- Trans. Amer. Ophthal. Soc., Vol. X, pt. I, p. 45 I, 1903.

24. Paul. -Arch. f. Augenheilk., Vol. LIII, p. I, I905.

25. Chiarini.-Boll. R. Acc. Med. di Roma., Vol. XXXII, 1907. Ref. Centralbl. $f$. Augenheilk., Vol. XXXI, p. 447, 1907.

26. Proctor and Verhoeff. - Archiv. of Ophthal., Vol. XXXVI, p. 47, I907.

27. Toulant. - Arch. d'Ophtal., Vol. XXXV, p. 44, 1916.

28. Brewitt.-Inaugural-Dissertation, Goettingen, 1903.

29. Ishihara.-Klin. Monatsbi. f. Augenheilk., Vol. II, p. 127, I914.

30. Hippel, v.-Klin. Monatsbi. f. Augenheilk., Vol. I, p. 743, I9I I.

31. Abelsdorff.-Arch. f. Augenheilk., Vol. XXXIII, p. 34, I896.

32. Chance. - Trans. Amer. Ophthal. Soc., Vol. XI, pt. I, p. I78, 1906.

\title{
ANNOTATIONS
}

\section{The International Congress of Ophthalmology (1925)}

At the International Congress of Ophthalmology held in Washington in April, 1922, Mr. Treacher Collins presented an invitation on behalf of all the Ophthalmological Societies of Great Britain and Ireland to hold the next Congress in London in the year 1925. The invitation was accepted on the motion of Professor Gullstrand, of Upsala, Sweden, seconded by Dr. Lucien Howe, of Buffalo, New York. A general committee consisting of representatives of the inviting Societies has since met and has formed an executive committee, empowered to make arrangements for the 1925 Congress. It is to be held in London during the four days, Tuesday, July 21 to Friday, July 24 . The three official languages are to be English, French and German. The subscription for membership has been fixed at the sum of $£ 2$. Invitations will be sent to the principal Ophthalmological Societies or other 
representative bodies in every nation, asking them each to nominate a delegate to the Congress who would be responsible for promoting its interests in the country which he represents, so as to endeavour to make it a great reunion of all those interested in Ophthalmology throughout the world.

The Executive Committee is composed of the following members :-Mr. E. Treacher Collins, Chairman ; Mr. J. Herbert Fisher, Vice-Chairman ; Mr. Ernest Clarke, Treasurer; Mr. Leslie Paton, 29, Harley Street, London, W., and Mr. R. R. James, 46, Wimpole Street, London, W., Secretaries; Mr. A. B. Cridland; Mr. J. B. Lawford; Mr. Humphrey Neame; Sir John H. Parsons, F.R.S.; Mr. A. H. H. Sinclair.

\section{The Blind and the Prevention of Blindness}

In recent years Ministers have recognized, more fully than before, their responsibilities in relation to the blind population of this country and much has been done by parliamentary action in alleviation of the hardships of those to whom sight is denied. In May, 1914, a Departmental Committee was appointed " to consider the condition of the blind and the means available for their industrial or professional training and their assistance, and to make recommendations." Its labours were temporarily suspended on the outbreak of war, but were resumed in March of the following year. The Report of this Committee appeared in 1917 (vide British Journal of Ophthalmology, Vol. II (1918), p. 29).

Reports by Government Committees do not invariably bear fruit, but happily in this instance definite action by the authorities followed the presentation of the Report. One of the earliest results was the appointment by the President of the Local Government Board of an Advisory Committee on the Welfare of the Blind, composed mainly of men and women already engaged in work among the blind and including several who were themselves blind. This Committee was a temporary one and after three years of very valuable work was replaced by a permanent Committee, representative of the registered Societies and Associations for the assistance of blind persons. In 1920 fresh legislation in the interests of the blind was introduced in Parliament and in that year two bills were passed, both of which conferred material benefits on the blind. They are known as the "Blind Persons Act, 1920 " and the "Blind (Education, Employment and Maintenance) Act, 1920." The opening clause of the first of these confers on blind persons the right to the old age pension at the age of fifty. Sighted persons are not eligible for this pension until they attain the age of seventy.

One of the first actions of the original Advisory Committee was the appointment of various sub-Committees, to one of which was referred the important question of the prevention of blindness. It 